\title{
MACHINE-READABLE LAW AND ITS PROSPECTS IN UKRAINE
}

\author{
МАШИНОЗЧИТУВАНЕ ПРАВО ТА ЙОГО ПЕРСПЕКТИВИ В УКРАЇНІ
}

\author{
Riazantseva Y.O., Student of the Faculty of Economics and Law \\ Yaroslav Mudryi National Law University
} The topic of law automation or LegalTech is relatively new to domestic science. Today, lawyers primarily make researches about usage of technologies
simplify access to justice, but law of the future will receive a technological element and will become machine-readable and self-executable.
The article is devoted to machine-readable law, its origin, connection with the three waves of development of the movement for access
justice, ethical and moral problems of its implementation and functioning. The author also paid attention to assessing the effectiveness
machine-readable law and law in general. The transformation of the system of interaction in the legal field does not change the very essence
law, therefore, the author concludes that machine-readable law is just another stage in law's development and it is one more attempt to
olve better the problems law faces. The author notes that machine-readable law is not an end in itself; it should serve the interests of society.
onventionally, the author identifies three phases in the development of machine-readable law - the solution of individual problems (preparatory
age), processes' algorithmization and rules' comparison. The result should provide comprehensive support of the entire legal systems.
The author explores approaches to the introduction of machine-readable law in the world and identifies two - Estonian and New Zealand. The
stonian type is characterized by: focus on solving specific problems, the goal is to satisfy the needs of citizens. At the same time, the New Zealand
pproach is comprehensive and includes long-term research, the goal is a comprehensive transformation of law system to machine-readable.
Further, the author compares the Ukrainian legal reality with the above approaches and concludes that Ukraine follows the Estonian
lot of work left.
Key words: machine-readable law, perspectives of machine-readable law in Ukraine, factors for estimating the effectiveness of machinereadable law.

Тема автоматизації права, або LegalTech, є відносно новою для вітчизняної науки. Нині юристи переважно досліджують застосування інформаційних технологій для спрощення доступу до правосуддя, але право майбутнього отримає технологічну оболонку і стане машинозчитуваним та само-виконуваним.

Стаття присвячена машинозчитуваному праву, його зародженню, зв'язку з трьома хвилями розвитку руху за доступ до правосуддя, етичним та моральним проблемам його впровадження та функціонування. Окремо автор приділила увагу оцінці ефективності машинозчитуваного права та права в цілому. Перетворення системи взаємодії в правовому полі не змінює саму сутність права, тому робиться висновок, що машинозчитуваність права - просто ще одна віха в його розвитку і намагання ефективнішого розв'язання проблем, що стоять перед ним. Наголошується, що машинозчитуване право - не самоціль, воно має слугувати інтересам суспільства. Умовно виділяється три віхи в розвитку машинозчитуваного права: розв'язання окремих проблем (підготовчий етап), етап алгоритмізації та етап порівняння правил. Фінальний результат має надавати всебічну підтримку правової системи.

Автор досліджує підходи до впровадження машинозчитуваного права в світі і виділяє два - естонський та новозеландський. Для естонського типу характерні зосередженість на вирішенні конкретних проблем, його мета - задоволення потреб громадян. Водночас новозеландський підхід є комплексним і включає довготривалі дослідження, його мета - комплексне перетворення системи права на машинозчитувану.

Далі дослідниця порівнює українську правову реальність із названими підходами і робить висновок, що Україна наслідує естонський підхід. Стосовно перспектив машинозчитуваного права в Україні зазначається, що вони є обнадійливими, але ще багато роботи.

Ключові слова: машинозчитуване право, перспективи машинозчитуваного права в Україні, фрактори оцінки ефективності машинозчитуваного права.

Challenge problem. Machines' spreading changed many things in the life of society. Internet has significantly accelerated human's interaction. Law could not avoid changes, as it is a social regulator. Because of this, researches in the sphere of law's evolution is needed due to changes in social interconnection.

The one route of such evolution is to make law machinereadable i.e. understandable to mechanical devices. The machine in this case is understood as a computer or a computing device mainly. There are different methods to change law's transmitting in a machine-readable form - law's coding, juridical programming, markup, artificial intelligence. However, all such methods have a lot in common - history, aim, tasks, principles etc.

Through law's history the role of its transmission were the same - connection between people for people on language understandable for people. The form of law's record was not a subject to shifts. Sure, the switch non-written to written, and introducing usage of computers in transmitting of law were important, but law's transmission has not been changed such drastically from the time of its origin. It is because humanity has not met such new subject before computer was invented.

Now new opportunities in interaction between people and law appeared exactly because of machines' spreading. They can analyze, provide personified data, produce statistics, so people can make decisions based on an objective reality.
The "next step" in computers' usage is deeper integration and better machines' involving in the processes, which need minimum of human attention and human's features e.g. enforcing of human-made decisions, simple counting in accordance with specified criteria.

And this "first new step" is being done now. Because of this, it is needed to reflect about further movement and what it will bring to us. Hence the question, how to make machines understand law and what humanity will gain from this, is a burning problem, despite the fact that social demand on machine-readable law now is not high.

Purpose of the article is to make a legal research of basic ideas in the sphere of machine-readable law and make a speculation about prospects of its implementation in Ukraine.

Results of analysis of scientific publications. The problem of machine-readable law was researched mostly by foreign scientists; they are Michael Genesereth, Rinke Hoekstra, Marcello Di Bello, Anton Vashkevich, Monica Palmirani, Guido Governatori. Mostly, the works are dedicated to one aspect of machine-readable law e.g. ethic, efficiency, specific method of its implementation, for example, Daniel Faggella and his "AI in Law and Legal Practice - A Comprehensive View of 35 Current Applications" etc.

The otherimportant feature is the high activity of researchers' groups, for example, OASIS and its LegalRuleML TC. Such groups may be connected with universities e.g. CodeX: 
The Center for Legal Informatics Stanford University, Institute of Legal Informatics, Leibniz Universität, Bucerius Law School, University of Hamburg Norwegian Research Center for Computers and Law at University of Oslo etc. Also, such researches may be held by governmental bodies or on state's demand, for example, New Zealand's government sponsored research "Better Rules for Government Discovery" and got scientists as civil servants to make researches in the sphere of machine-readable law.

Over the 2019 year the book "Machine-readable law: Law as electricity" was created by Anton Vashkevich. The work is unique because the author made complex research (the book contains themes from law's efficiency to estimation of the rule's automation potential) and put the information in reader-friendly way. At the same time, there are no enough existing works. Researches in the sphere of machine-readable law must be continued.

Statement of conceptual issues. The history of discussion about making law machine-readable started in 1960th with the conference at University of California, Los Angeles. It was dedicated to usage of electronic data in justice. Scientists were inspired by the idea of evolution of law and its connection with new electronic techniques. It was said on this conference that methods of 1960th will bring frustration of legal research. It was mentioned, that machines are not a panacea. Interesting discussion was held about the language of the machine and the language of the law, during which the goals of legal researches in this sphere were presented. The debates about difference of language in codes and judges decisions, machines' language and machines' representation also is valuable for chosen topics. As in 1960th we need more predictability and accuracy in law enforcing, because of its conclusions made on this conference is useful in further researches [1, p. 104]

The contextual conception of the law [2, p. 283] motivates scientists to look at not only provisions and their quality, but also at law's effect. This contextual approach lead to access to justice movement, which was devoted to elimination of barriers to access to justice. These obstacles are divided into 3 groups: social, organizational and procedural. On the ground of this groups, the 3 -waves concept in the access to justice movement was created by Cappelletti [2, p. 283-288]. First wave is connected with elimination of social obstacles and reforming of legal help for poor. Second wave is connected with introduction of lawsuits, that could protect many people group suits, suits of associations and unions. Third wave is connected with an alternative dispute resolution.

The similar reasons aroused the "making law machine readable" discussion. It will also contribute to resolving issues related to access to justice. It will make people closer to law by better understanding and simpler enforcement of rules. Courts will be able to use software to resolve simple cases and cases' analysis can help with similar suits. Alternative dispute resolution will also be more successful with the implementation of machine-readable law, and the pressure on the courts will decrease.

Modern scientists try to answer the question about ethical and moral approaches to machine-readable law. It is controversial question about the level of machine's interference into the law procedures (including lawmaking, law interpretation and law enforcing). The huge human's role in creation law is doubtless provision. Now only human can analyze society's needs and find the best way of their satisfaction on our level of progress. Machine can help people in different forms including controlled transforming law on natural language to machine-readable one, formation of analytic models, data selection and its sorting. The other sphere in which machine cannot replace people is judges' discretion. Yes, machine can make pre-decisions or serve in some sorts of cases, but it is impossible to use only machines in such area.
Machine-readable law is supposed to resolve the problem of inefficiency of law (including its enforcement). The counting of such efficiency is complex procedure. There are many different approaches - from counting of laws' application to estimation of social effect and acceptance of law by citizens. There is also interesting set of factors to evaluate the effectiveness of machine-readable law in Vashkevich work [3, p. 17-18]. According to his approach, to be effective machine-readable law should provide:

- univocal interpretation and enforcement of law;

- boost of legal procedures and processes;

- reduce transactions' costs;

increasing of legal certainty.

These factors are connected with characteristics of law in general. It is because of two things. Firstly, machine-readable law does not end in itself. The aim of instructing the machinereadable element in law is to make law more efficient and improve social regulation, simplify lawyers' job etc. Secondly, only way is supposed to be changed, not object. Law is still law and machine-readability is only about the way of its transmitting and analyzing.

The approach to transformation must be complex. So, the law should be machine readable from the very beginning of their existence to the very finish of their application. It is not only about laws themselves, but also about the system of relationships between states, their bodies, citizens, business and civil society.

The very beginning of developing machine-readable law is resolving of separated issues. Such issues are e.g. fast search in existing legislature, markup and automatic enforcing on the simplest level (for example, automatic debiting fines from bank accounts). The processes' algorithmization and rules' comparison is a next two stages in making law machinereadable. The result should constitute almost entire complex system of technologies, which provides comprehensive support of the entire legal systems. It may be called in different ways, for example, Vashkevich names it "The Framework" [3, p. 23-25]. The exemptions from machine's autonomy in such system are control, making special discretion decisions and instruction some data.

Resolving of technical tasks does not guarantee successful introduction of machine-readable law in a society's life. Because of it, this is important to form social acknowledgement and acceptance of new procedures. The instruments of such formation are informing with video, infographics, articles; educational programs; simple and interesting instruction; transition period and some preferences for users at first time. In addition, researches in the area of efficiency of new procedures is desirable. It is needed to create unified obligatory methodology for measurement of efficiency of new way of law's existence in society and measure the effect economic, social, ecological etc.

World approaches. According to the research carried out under the article's preparation, the most demonstrative examples of attitude to machine-readable law are Estonian approach and New Zealand one.

Estonia shows good results in the sphere of digitalization of government services and machine-readable data. There are decentralized registers in Estonia and they exchange requested information instantly. Data is very important not only from the perspective of government services, but also for machinereadable law.

Success in digitalization of government services may slow down process of making law machine readable. E-law in Estonia is understood as a possibility to read legislation through the internet [4]. Estonian system works quite good in a short-term perspective. It shows results here and now. It is possible to pay taxes in 5 minutes there and get $99 \%$ of government services online [4], but if a legislation changes, it is needed to change system. The aim of machine-readable law is not to adapt system to new rules. Machine-readable law 
is about drafting law in special form, so system will change automatically. Estonian way is used in many countries e.g. Finland, Kyrgyzstan, Iceland, Japan.

The closer way to make law machine-readable is a New Zealand ones. There were held complex Discovery Sprint [5], which is deep research about way of development legislation to make law machine readable, method of creation such law, equivalency between machine-readable rules and such on natural language, efficiency of service delivery and principles of machine-readable law. "Law as code in New Zealand" is ongoing investigation that shows complex approach to machine-readable law, while examining "the legal, social, constitutional and democratic implications of converting, drafting and consuming legislation in machine-readable computer languages, commonly known as code" [6]. Furthermore, Openfisca created a Rapu Ture [7] - machinereadable part of New Zealand's legislation, which code is used under an Affero General Public License free, copyleft license, that boost further researches. New Zealand's government also researches rules-as-code and has "better rules discovery" project [8].

Ukrainian approach. In September 2019, the Ministry of Digital Transformation was created by reorganizing old State Agency of Electronic Governance through Transformation. Decree about Ministry of Digital Transformation does not contain provisions about machine-readable law and its development in Ukraine. The plan of work of the Ministry of digital transformation in 2020th contains paras about [10]:

1. Governmental services.

2. E-ID.

3. Optimizing of governmental registers and their cooperation.

4. Fast internet.

5. Digital literacy.

6. Helping and development of information technology (IT) industries.

From analyzing tasks, it is seen, that Ukraine and the Ministry of Digital Transformation took "Estonian" model. The aims of the Ministry of Digital Transformation also evidences that approach of concentration on the services was chosen. Such aims are [10]:

- $100 \%$ of public services available to citizens and businesses online;

- providing $95 \%$ of transport infrastructure, settlements and national high-speed Internet access services;

- teaching 6 million Ukrainian digital skills;

- increase the share of IT in the country's Gross Domestic Product to $10 \%$

As we can see, it is good aims, but there are no researches in machine-readable law sphere and there are no attempts to create, develop and introduce machine-readable law in Ukraine.

Ministry of Justice has no aims about machine-readable law too. In addition, Ukraine does not have a strategy for digital transformation with deadlines. The Concepts of development of digital economy and society of Ukraine for 2018-2020 and approval of the plan of measures for its implementation is not enough because it has no measures in the sphere of machine-readable law.

It seems appropriate to create a law on such measures with provisions about aims, control, and responsibility of persons in charge. The Law of Ukraine is better than the Decree because the parliament is granted with powers from the citizens directly and the decisions made by parliament will have better social support and will be more complex. Also, social discussion in the process of adoption such law will attract people's attention to the problem of machine-readable law.

The question about good or bad is "Estonian" model is insoluble. From the short-term prospective of view the best way is to solve problems after they appear. It is easier, cheaper and clearly visible to citizens. From the long-term prospective of view, the best way is to create system with involvement of machines, which will cause less errors and troubles or it will not cause problems at all in ideal situation, which is obviously preferable. In addition, "Estonian" model may be a good springboard for better introduction of machine-readable law. Of course, each country chooses unique solution, but from my prospective of view, the long-term approach is better, despite the fact, that it is more expensive.

Conclusions. Ukrainian prospective. Keeping in mind Ukrainian approach and the purpose of the article, it seems appropriate to continue researches in the sphere of machinereadable law. Such investigation should answer the questions:

- which method of making law machine-readable is suitable for Ukraine;

- from which areas of society's life it is better to start;

- which measures should be taken to attract people to new processes; counted.

how efficiency of machine-readable law could be

Ukraine has huge amount of internet users, so fast data collection started with the assist of DIIA application. Diia is intended to provide governmental services too, thus this is a step in the direction of introducing machine-readable law. Ukraine is developing the net of state registers, which also serves for making law machine readable in a long-term perspective. It seems that perspectives are encouraging, in spite of this, further work, analysis and comparisons is needed to make law machine readable and provide the best law transmission to society that it needs.

\section{REFERENCES}

1. Chasalow I. The UCLA National Law and Electronics Conference [notes]. M.U.L.L. Modern Uses of Logic in Law. 1960. № 2. P. 102-109.

2. Cappelletti M. Alternative Dispute Resolution Processes within the Framework of the World-Wide Access-to-Justice-Movement. The Modern Law Review Limited. 1993. № 56. P. 282-296. URL: https://onlinelibrary.wiley.com/doi/pdf/10.1111/j.1468-2230.1993.tb02673.x.

3. Вашкевич А.М. Автоматизация права : право как электричество. Москва : Симплоер, 2019. 256 с.

4. Estonian solutions on security and safety. URL: https://e-estonia.com/solutions/security-and-safety/e-law.

5. Better Rules for Government Discovery Report. URL: https://www.digital.govt.nz/dmsdocument/95-better-rules-for-government-discoveryreport/html.

6. Investigation "Law as code in New Zealand". URL: https://www.brainbox.institute/legislation-as-code-in-new-zealand.

7. Rapu Ture - Exploring the Rules. URL: https://www.rules.nz/.

8. Global coverage of our legislation as code work. URL: https://www.digital.govt.nz/blog/global-coverage-of-our-legislation-as-code-work/.

9. The plan of work of the Ministry of digital transformation in 2020th. URL: https://thedigital.gov.ua/storage/uploads/files/page/ministry/\%D0 \%9F\%D0\%BB\%D0\%B0\%D0\%BD_\%D1\%80\%D0\%BE\%D0\%B1\%D0\%BE\%D1\%82\%D0\%B8_\%D0\%9C\%D1\%96\%D0\%BD\%D1\%86\%D0\%B8 \%D1\%84\%D1\%80\%D0\%B8 \%D0\%BD\%D0\%B0 2020\%D1\%80\%D1\%96\%D0\%BA.pdf.

10. Aims of the Ministry of Digital Transformation. URL: https://thedigital.gov.ua/ministry. 